\title{
Thoughts on the Manifesto for Democratization of Europe in the Light of Fiscal Powers
}

\author{
Zeynep Müftüoğlu ${ }^{1}$ \\ N.Nilay Dayanç Kuzeyli
}

\section{ARTICLE INFO}

Submitted : 01.03.2021

Revised : 28.10 .2021

Accepted : 22.11.2021

Available : 25.12.2021

iThenticate similarity

score: $13 \%$

JEL classification:

K34, H61, H23

Keywords:

The Manifesto for Democratization of Europe, Democracy, Budget Right, Tax Competition, Ability to Pay, Carbon Tax

\begin{abstract}
A B S T R A C T
Today we are witnessing almost the widest gap between the richest and the poorest. Besides the economic aspect of inequality, democracy deficit, acceleration of global warming, urgent needs to adopt sustainable development can be considered as main problems of today's world. Current national and international models are being insufficient to address these problems. Taxation one of the is the main mechanisms to struggle these problems. However, European Union does not have a strong mechanism to adopt tax measures. European Union institutions lack the democratic legitimacy that would be needed to have tax-raising powers. Considering that challenge The Manifesto for the Democratization of Europe constitutes an essential effort to tackle these problems with its concrete suggestions. Suggestions in the Manifesto are easily filling the gaps in the existing system in Europe. The system envisaged in the Manifesto is focusing on the European Assembly especially with its tax-raising and expenditure power. The mechanism is also novel, in the sense that it leaves the traditional way of budgeting. In this article, the authors aim is to identify and evaluate the suggested model of the Manifesto and the Treaty on the Democratization of Europe.
\end{abstract}

Cite this article as: Müftüoğlu, Z. \& Dayanç Kuzeyli, N.,N. (2021). "Thoughts on the Manifesto for Democratization of Europe in the Light of Fiscal Powers", International Journal of Public Finance, $6(2), 211-232$.

\footnotetext{
1 Assist. Prof. PhD., Atılım University, Department of Law, Turkey, ORCID: 0000-0003-2569-5155, zeynep.muftuoglu@atilim.edu.tr

2 PhD. Lec., Bilkent University, Department of Law, Turkey, ORCID: 0000-0003-2036-3135, dayanc@bilkent.edu.tr
} 


\section{Introduction}

Analysing historical development process of the fiscal powers; particularly the taxing power, it becomes noticeable that these powers have a strong relationship with the progress and development of democracy, one affecting the other directly. The most distinct example of this effect can be found in the Magna Carta Libertatum, which was signed on 1215 between the King John of England and barons because of discretionary and unlimited use of the taxing power by the kings. With the Magna Carta Libertatum, the King's taxing power was limited for the first time in the history. Centuries after the signing of the Magna Carta Libertatum, in 1700s, the parliaments also had a say in the public spending and were empowered to control public revenues and expenses. Thus, the budget right can be referred as the public have control over the public revenues and expenses and it is used by the parliaments through their elected representatives.

Today a new and exceptional progress has been made within the agelong relationship between the democracy and the fiscal powers. At the end of 2018, "Manifesto for the Democratization of Europe" (the Manifesto) has been prepared and released to the public under the leadership of economist Thomas Piketty with the contribution of approximately two hundred people in variety of fields such as law, political economy and politics. In addition to the Manifesto, a draft agreement named "Treaty on the Democratization of the Economic and Social Government of the European Union " (T-DEM) has been prepared with the aim of reflecting the suggestions in the Manifesto concretely. Both the Manifesto and T-DEM include the democracy demands of the European Union (EU) and carry the concern that the EU may be disintegrated if not democratized.

In the Manifesto and T-DEM, it is suggested to establish a European Assembly (the Assembly) and empower it to impose income tax, corporate tax, wealth tax and carbon tax. Addition to these powers, in the texts it is proposed to constitute a European budget consisting of these tax revenues and give the power to spend such revenues to the Assembly within the scope of the determined objectives of the Manifesto. It is important to pay attention to the detail that the Manifesto and T-DEM are derived completely from civil initiative and are not bounding under the EU Law. These texts are opened for the signature and discussion of the public and aim to be developed and be leading for policies for the future of $\mathrm{EU}^{5}$.

Within this framework, the evaluation of Manifesto and T-DEM, the draft treaty constitutes the center of this study. In the first part of the study, the historical relationship of the development of democracy and the fiscal powers is examined.

\footnotetext{
3 Manifesto for the Democratization of Europe, http://tdem.eu/en/manifesto/, (13.02.2020).

4 Treaty on the Democratization of the Economic and Social Government of the European Union, http://tdem.eu/en/treaty/,http://tdem.eu/wp-content/uploads/2018/12/BUDGET_EN.pdf, (13.02.2021).

5 To see the signatories please visit: http://tdem.eu/en/signatories/.
} 
Therein the importance of the Manifesto was identified in connection with historical background. After such examination, the European Assembly, the democratization budget, the taxation power and the expenditure power are analysed respectively. In the conclusion, it is planned to draw a framework to the system suggested by the Manifesto and the T-DEM through the thoughts and suggestions of the writers.

\section{Reading the Relation Between Democracy and the Fiscal Powers over the Manifesto}

Fiscal powers are an inseparable element of governing a state. Because of such integrated relation, it is possible to track the history of fiscal powers back till the formation of any governing structure. But when it comes to the relation between democracy and budget right, according to some writers it is not possible to determine the beginning of such combination (Feyzioğlu, 1984: 16). In some other sources it is claimed that budget right is like the cradle of democracy and these two notions are coeval (Bulutoğlu, 2004: 74).

\subsection{Historical Aspect}

\subsubsection{Birth of Representative Democracy}

When examining the relationship between democracy and budget right, Magna Carta can be accepted as a primary milestone. Kings' using their fiscal powers in an unlimited way till $13^{\text {th }}$ century, especially taxation, caused intense displeasure among the people living in England. To provide peace in the country, the King had to compromise with the barons and they conducted the Magna Carta that is based on the oath to respect for rights and liabilities mutually ${ }^{6}$. Although such text cannot be defined as a complex constitution, it has a great importance since it brings limitation to the use of king's powers for the first time in the history (Andrew, 2015: 39; Gürsoy, 1978: 58, Passant, 2016: 68). Such limitation gave rise to the birth of representative democracy (Andrew, 2016: 45-51; Çağan, 1985: 199) and such democracy is carried out through parliaments. So it can be seen that the first parliaments, in the way we understand today (Alan, 2005: 170), were established against the unlimited taxation powers of kings. Considering that development, the first powers that parliaments gained was taxation power (Inter-Parliamentary Union, 1962: 203; Maddicott, 2012: 166, Passant, 2016: 68-70) and the Magna Carta established a 'link between taxation and consent' via the parliaments (Maddicott, 2015: 22)

After taxation power, the parliaments gained the spending power and the audition power as well. The developments between $13^{\text {th }}$ and $17^{\text {th }}$ centuries, caused the birth of representative democracy and provided radical changes in the perception of the powers of the king and the rights of the public. The mentioned three phases;

\footnotetext{
${ }^{6}$ The Magna Carta (The Great Charter), Article 12, https://www.constitution.org/eng/magnacar.pdf (11.03.2019).
} 
gaining taxation power, spending power, audition, constituted budget right and these phases are accepted as the elements of this right.

These enhancements experienced in England spread to France in $18^{\text {th }}$ century (Harding, 2005: 160) with the Declaration of Human and Civic Rights ${ }^{7}$ (Feyzioğlu, 1985: 22). Then it spread all over the Europe (Edizdoğan vd., 2016: 23, 24; Sayar, 1965: 2628) and America as well.

\subsubsection{Birth of No Taxation Without Representation Principle}

With no doubt, every country has its unique experience throughout the history but America needs to be held by its own briefly in this study. With the Magna Carta, representative democracy was born and the parliament had a say on the public revenue. With the American Revolution this gain turned into the slogan "no taxation without representation"- an important component of the siren song of equality- with a similar process which sparked the Magna Carta(Passant, 2017: 23). This principle led the American colonies to fight for independence from the British Empire (Saundes, 2019: 35). Historically, the main function and importance of the parliament is giving consent to taxes. The American revolutionaries considered it unacceptable to pay taxes to a government in London but not being represented in the British parliament (Saunders, 2019: 36). So a boycott of British goods was started to resist against British taxes and control but later the rebellion was no longer just about tax but about both the heavy handedness of London, and the lack of representation of Americans in British parliament (Passant, 2017: 27). So it can be said that a major, public cause of the American Revolution was the imposition of taxation and such imposition served to increase awareness of the right to representation and promoted collective bargaining with rulers (Kato, Tanaka, 2019: 184) With this awareness, the no taxation without representation principle became one of the founding principles of the American republic (Saunders, 2019: 46) and one of the basic assumptions of the modern theory of representation and of the legitimacy of parliaments (Fasona, 2014: 185).

In all these countries, although the timing and extent was different from each other, the common point was the use of taxation power in an unfair way causing democracy demands. So as can be seen, these dynamics are not just about the mentioned countries and they are not just of the past (Passant, 2017: 27). Also one can say that democracy is not only about taxes or where the revenue is spent. It is political, economic, social (Passant, 2017: 27). That is why it is still an argumental issue.

\subsection{Democracy Deficit and Demands in Europe}

Today, in the $21^{\text {st }}$ century, we again witness a democratization demand through fiscal powers. This time, such demand is arising from the concern for the future of the

\footnotetext{
7 Declaration of Human and Civic Rights, Article 14 https://www.conseil-constitutionnel.fr/ en/declaration-of-human-and-civic-rights-of-26-august-1789, (17.03.2019).
} 
EU. With this Manifesto, it is aimed to end the democracy deficit which is seen as a "black hole (Hennette et al., 2019: 2)". The democracy deficit was an issue to be fixed for a long time in EU and many efforts were put in papers (Manzella, 2018: 94-96, Brack et al., 2018: 45, Fasona, 2014: 169-180) but still, it is possible to say that to a certain extent, democracy remains a blind spot in Eurozone reforms (Barbou, 2018: 8). Such deficit is considered to arise from the lack of parliamentary control against significant strengthening of the executive capacity of European institutions in many major fields (Hennette et al., 2019: 63, 64).

To promote democracy, empowering the existing institutions is one of the supported solutions (Crum, 2018: 63, Brack et. al., 2018: 56, Barou, 2018: 15). The main differentiating side of the Manifesto from other suggestions is leaving the plan to renegotiate the treaties (Cabanes, 2019) and proposing to create a democratic structure to prevent the EU from disintegration.

Another reason for the democracy deficit in EU, as the writers of the Manifesto reveals, is the accession deadlock to the decisions taken by the Euro-summit and to the negotiations held within the Eurogroup and its working committees. With the awareness of this reason, the writers of the Manifesto aim to change the marginal position of the European Parliament in Eurozone governance. In other words, with this proposal, 'democratic disconnect' in the EU is tried to put an end. (Lupo, 2018: 84, 85).

Besides democracy deficit, the T-DEM also draws a way to change the absence of economic policy that is compatible with social Europe. The T-DEM is doing this through linking self-determination at nation-state level with a transnational democracy (Aidnick, 2019: 246). This point of view also changes the merits of what is national. Comparing to ten years ago, today, most of the national concerns are now handled through a Europe-wide level. A cross border solutions at international level is a necessity considering the international characteristics of today's problems such as climate change or tax competition. The Manifesto and T-DEM argues to put democratization in life within a harmonized democratic framework in the name of the governance of the eurozone (Hennette et al., 2019: 164). Through the abolishment of a supranational integration and international cooperation in Europe, a 'from bottom up' democracy and solidarity is being tried to shaped (Brack et al., 2018: 45) From this point of view, it can be observed that the ambition of the T-DEM is not to improve the efficiency of Eurozone, but to promote its democratization (Barbou, 2018: 9). It is regarded as a second era for a modern, peaceable Europe (Adelman \& Delatte, 2019:9)

In the way of promoting democracy, "structural underinvestment in the public sector, particularly in the fields of training and research; a rise in social inequality; acceleration of global warming; a crisis in the reception of migrants and refugees" are the reasons listed that give rise to the preparation of the Manifesto and the T-DEM (Bouju et al., 2019: 186). 


\subsection{A General Critic of the Manifesto}

The aim of the Manifesto is to implement a system of social, fiscal and environmental justice in Europe. But when examining the Manifesto over democracy, the question 'if the aim is democratization, why democratizing the Eurozone but not EU in general? (Barou, 2018: 15)' is left unanswered. On the other hand focusing on the democratization of Euro area can only contribute to the solution of the democracy deficit at a European level and problems at the national responsibility of governments will remain the same (Allemand, 2018: 42, 43).

Another issue that needs to be criticized about 'Euro zone-national' level is about the decision-making process. The problems rising from the unanimity requirement for modifying the treaties is tried to be solved by organizing an intergovernmental treaty but this attitude carries the risk to 'shift the battle field' towards the decision-making process at the national level (Cabanes, 2019). With no doubt, such shift will cause new instabilities and complexity.

\section{The European Assembly}

In the Manifesto, creation of a European Assembly is proposed, and such proposal is grounded on the wish to get Europe out of the present technocratic impasse. The aim underlying the creation of a new assembly is not only to enable to prepare an area to discuss the powers foreseen for the new initiative but also to give chance to parties, social movements and NGOs to express themselves. The new form of the Assembly is described as the keystone of the mechanism to permit the European people to reappear on the political seen (Kamtsidou, 2019: 132).

\subsection{Democracy Promoting Composition of the European Assembly}

\subsubsection{The Functions of the European Assembly}

Since the powers and the rights of the Assembly is noticeably wide, the composition and the working process is explained in the T-DEM as well. When the information about the Assembly in the Manifesto and the articles in T-DEM are examined, one can say that the Assembly is the core unit of the new initiative. The focus point in the composition and working procedures of the Assembly is to provide pluralism, compromise and democracy. The T-DEM sees the Assembly the place to democratise economic decisions through public debates and votes by different kinds of elected representatives (Rozenberg, 2018: 122).

In the Manifesto, this cooperation, particularly the one with national and European parliamentarians, is claimed as "by granting national elected members a central role, the national, parliamentary elections will de facto be transformed into European elections... By bringing together the national and European parliamentarians in one single Assembly, habits of co-governance will be created which at the moment only exist between heads of state and ministers of finance..." (Hennette et al., 2019: 3). 
Müftüoğlu, Z. \& Dayanç Kuzeyli, N.,N. (2021). "Thoughts on the Manifesto for Democratization of

Europe in the Light of Fiscal Powers", International Journal of Public Finance, 6(2), 211-232.

Another aim of such cooperation is also shown as preventing the responsibility simply shifting from national elected members on to Brussels and making the elected members explain the projects and budgets to the voters (Hennette et al., 2019: 3).

\subsubsection{The Composition of the European Assembly}

In the light of aims mentioned above, both papers support the cooperation of the Assembly with national parliaments and all the relevant parties. This point of view directly finds a reflection on the composition of the Assembly. As to Article 4 of T-DEM, "the number of the Assembly shall not exceed 400". From such number it can be thought that it is aimed to prevent probable blockages in decision making that might arise from the lack of compromise when the number is high. Regarding the same Article, the four fifths of 400 members which is $80 \%$ shall compose from the representatives of the national parliaments. In such composition it is regulated that national parliaments will contribute with the proportion of groups within them. By such proportion, it is easy to see that a fair representation is tried to be set. By this means, the structure can be described as 'a regular link between national and European parliamentarians' (Allemand, 2018: 35). Addition to that, the national level decisions in particular sensitive areas, such as national budgets or national economic policies, are strictly bound to political groups and citizens of the countries. Regarding such relation, it is a good step for the T-DEM to gear the system towards the representation of national interests (Brack et al. 2018: 48).

Such regulation is also parallel to the aim that Assembly "shall work in close cooperation with the European Parliament", which is emphasized in the Article 3 of TDEM. The rest one fifth of the Assembly which is $20 \%$ consists of the representatives that the European Parliament designates. This latter in the combination of the latter proportion is translated as the reflection of the concerns to grant popular legitimacy into economic decisions of the EU through rising populism (Rozenberg, 2018: 122). Also with such mechanism political pluralism will be provided as well.

Again, in the aim of pluralism and representativeness, "the number of members of the Assembly designated within national Parliaments shall be fixed in proportion to the population of the Member States." In this rule, to guarantee the participation, it is set forth that each national parliament of the contracting parties will be sending at least one representative. With such formation, the problems arising from the lack of political accountability is aimed to put an end (Hennette et al., 2019: 3). But in a democratization centered Assembly, one representative by member state can be found conflicting. In this calculation, small political groups will hardly send representatives to the Assembly. (Brack et.al. 2018: 51) since the national parliaments will decide which members will be in the new Assembly (Lupo, 2018: 90). So it can be more suitable with the democratization movement to envisage at least one representative from the main opposition party of the member states to send delegation to the Assembly (Rozenberg, 2018: 125). 


\subsection{Functions and Powers of the European Assembly}

In the Manifesto and T-DEM, the Assembly is stated as the "involvement of parliaments in steering and control". This approach is the opposite what the Member States of EU, Commission and the European Central Bank did after the 2008 crisis. Because the solution applied by these actors to combat with the crisis was "strengthening of the executive capacity of European institutions in the field of economic, budgetary, fiscal and social policy". By the involvement of parliaments in the Manifesto, it is aimed to put an end to the absence of "respect and maintenance of representative democracy" and the democratic legitimacy deficit it has caused (T-DEM, 2018: 1). So one can say that the aim in the Manifesto and the T-DEM is to inject a dose of parliamentary control' in economic and monetary decisions so that when executive and parliamentary poles can convergence and intervene (Barou, 2018: 11).

Regarding the main roles given to the Assembly, it needs to have well defined powers not the congest during the processes (Adalid, 2019: 30). In accordance with the targeted functions, the Assembly is entitled with some powers. ${ }^{8}$ Through such powers, the Assembly is using the power to vote that is delegated from the member states on the budget, tax and expenditure (T-DEM, 2018: 3). Since the Assembly is composed of both members of national parliaments and members of the European Parliament, citizen representation is tried to be provided in listed decision-making processes (Aidnick, 2019: 245)

Mechanism, which is an initiative to "provide financial assistance to euro area countries experiencing or threatened by severe financing problems ${ }^{9}$." Throughout all these functions, the Assembly is put in an position as a counterweighted to the European Council and the bureaucracy and diplomatic network (Magnette, 2019: 96). In Article 17 of T-DEM, giving the power to the Assembly to approve the candidates listed above can be interpreted as putting the Assembly on top of all the current mechanisms in EU. But one should also argue that in the way of democratization, is it a rational and effective choice to ignore the operational tools and procedures that the EU has already put in place through a more intense parliamentarization? (Manzella, 2018: 93, 94) And it is still not clear whether the powers vested in Assembly are sufficient to deal with democratic issues in the coordination of national economic policies (Adalid, 2018: 19, 20) or the new Assembly has the required time to carry out their duties properly (Adalid, 2018: 28).

\subsection{Legislation, Steering and Convergence Powers of the European Assembly}

Based upon the functions and the powers, one can find further information in T-DEM about the exercise of legislative competence in Article 10, ordinary legislative procedure in Article 11, steering and control of the economic and social government in

\footnotetext{
8 Taxation power of the Assembly is explained under '5. Taxation Power of the European Assembly' in detail.

9 European Stability Mechanism, https://www.esm.europa.eu/assistance/lending-toolkit\#lending_ toolkit, (24.03.2020).
} 
Article 12, convergence and coordination of economic and budgetary policies in Article 13, financial assistance facility in Article 14, governance dialogue with the European Central Bank in Article 15. With described mechanism, the Manifesto and the T-DEM aim to resolve the structural weakness of parliamentarism against the dominance of the executives of the economic governance of EU and put an end to the imbalance between the executive and the legislative powers (Brack et. al., 2018: 47). In other words, the Assembly is set to function as a counterbalance to the executive power of the Eurogroup (Aidnik, 2019: 247).

As to briefly put on light on these regulations, it can be said that the Assembly needs to be in cooperation with the Eurogroup in many areas such as legislation or steering and control of the economic and social government policies. In Article 5 of TDEM the concept of "the Eurogroup", which is used to describe the composition of the ministers of the States whose currency is Euro, is tasked to "ensure close coordination and convergence of the economic and fiscal policies of States of the European Union". With mentioned dynamic composition, the Eurogroup and the Assembly, in addition to their cooperation areas listed above, shall also adopt the provisions required to the pool public debts exceeding $60 \%$ of each member state's GDP, through the issuance of common government bond.

'Hiding' a core and fundamental reform such as mutualisation of debt in exercise of legislative competence article can be criticized. It is obviously very important to make it transparent whether and how the debt be pooled for example. (Brack et. al., 2018: 51). But apart from that, such ratio is coherent with the Maastricht Treaty's debt ceiling. With listed regulations, a precondition to the reorientation of the economic and budgetary policies is aimed to be constituted. Such reorientation is seen as a greater consideration to fiscal and social convergence (Hennette et al., 2019: 68). But still, since the connection between democratisation and the mutualisation of debt is not underpinned, it is possible to say that such gap causes the T-DEM to lose the idea of democratizing the Euro area (Brack et. al., 2018: 51).

\subsection{Investigation and Control Powers of the European Assembly}

In Article 16 of T-DEM, since the Assembly is tasked with the "control of the institutions of the economic and social government of the EU" and it is expected to be "in close cooperation with the European Parliament".

Once again in the same Article, as a prophylactically choice, the Court of Auditors of the EU is tasked and charged with the assistance to the Assembly in exercising its control functions. Besides the Court of Auditor, the European Central Bank and the Commission are tasked to assist the Assembly as well. Their assistance is provided through the documents and data, the ones considered as useful in the exercise of its powers. 
Moreover, in Article 11, "the Assembly may hear any person assuming functions in an institution of the economic and social government of the Union." Such hearing is provided in the aim of ensuring transparency and accountability. Beyond any doubt, such tool is efficient and important in tracking the operations and keeping the Assembly updated. However, one cannot understand the nature of the "hearing" from the formulation of the Article whether such hearing is optional or the Assembly can assign the person to assist in a particular subject.

To list the other powers of the Assembly in budgetary policies, the Article 8 of T-DEM envisages the Assembly to adopt a position on the Semester report. This is a very important point, since budget surveillance is at the centre of the criticisms directed against the democratic deficit of the euro area (Platon, 2018: 106). With such position, it provides the Assembly to participate in the determining process of the necessary specific actions to correct the imbalance. It challenges the Eurogroup with entitling the Assembly to amend the imbalance report since the Eurogroup is to take the Assembly's observations into account. As can be seen the Manifesto and the TDEM is strengthening the European parliamentarism by giving the Assembly final say in case of disagreement with the the Eurogroup (Brack, 2018: 48).

\subsection{A General Look Over the European Assembly}

The Assembly is vested by briefly listed control power, but still there is a lack of responsibility-control-sanction mechanism (Müftüoğlu, 2019: 1759) which prevents the formation of budget right fully and this deficiency damages the democratization aims of the movement. Also the task for the Assembly to "work in close co-operation with the European Parliament", is clearly insufficient (Barou, 2018: 15).

What is certain is that multiply the number of overlapping parliaments will not resolve this challenge (Lupo, 2018: 91). It doesn't seem like a third institution after the national parliaments and the European parliament would provide authority and credibility. (Crum, 2018: 62, 63). It can even increase the differentiated institutionalisation which EU is already experiencing in eurozone, schengen, EU citizenship etc. (Brack et. al., 2018: 56). The duplication of parliamentary assemblies would also increase the risks of conflicts of competences, political contradictions and rivalries between them as well (Allemand, 2018: 36).Besides these risks the creation of such an Assembly runs counter to the principle of unity of the institutional frame-work and the representation of European citizens, (Allemand, 2018: 36).Addition to that, when proposing a new Assembly, one should take into account that existing European Parliament is against a new supranational parliamentary assembly (Lupo, 2018: 89). So it makes it even harder for the new structure to work. Another risk for the Assembly to fail in functions is that some of the members of the national parliaments will have 'double hat' role and that will have a significant effect on their duties such as attandance (Lupo, 2018: 89). 


\section{The Democratization Budget}

One can see that, when it comes to democratization demands, still in $21^{\text {st }}$ century, the first step is the establishment of a parliament and the second is empowering it with fiscal powers. Likely, in the Manifesto, "proposals are based on the creation of a Budget for democratization which would be debated and voted by a sovereign European Assembly (T-DEM, 2018: 2).

The budget prescribed in the Manifesto is defined as a 'democratization budget' and that is to meet the functions to fight against the inequalities at the European level, sustain the long-term viability of a genuine political model of social fair and sustainable development (T-DEM, 2018: 1, 2).

In Article 7, it is also aimed to insure that "all items of revenue and expenditure area shall be included in estimates", which is again suitable with the democratization characteristic of the budget. Then after classical budget principle is adopted and mentioned revenues and expenditures are expected to be drawn up each financial year. According to T-DEM, one can say that together the Assembly and the Eurogroup are the main actors in the preparation of the budget. The process held in Article 14 and 15 provide the parliament and the Eurogroup to adopt the budget together. It also ensures the parliament to push its own priorities against the Eurogroup through the proposal (Hennette et al.2019: 83). This mechanism of T-DEM, leaves the traditional way of budgeting and empowers the parliament in harmony with the budget right and its necessities.

The shared budget that forms the substance of the Manifesto represent significant steps to overcome the disparity between economy and democratic politics (Aidnik, 2019: 248). But still it has no provisions about eurozone economic stabilisation, risk sharing in the Eurozone, Eurozone assistance mechanisms, Eurozone accession support, reform of the own resources system, surveillance and coordination of national budgets, democratic oversight of the Eurozone and Union finances etc. (Crowe, 2018: 10). Because of not organizing most of the main public finance policies, these gaps inevitably weaken the T-DEM's budget system.

\section{Taxation Power of the European Assembly}

\subsection{The Scope of the Taxation Power}

According to the Manifesto, taxation is accepted as the main tool for the implementation of a system providing social, fiscal and environmental justice in Europe. Giving European Assembly the power to vote a common taxation system is regarded as the one of the most efficient ways to end fiscal competition and inequality (Budget, 2018: 1-3). In other words, the realization of the aims mentioned in the Manifesto is passing through taxation. With the budgetary income created by taxation, 
the budget is planned to finance ${ }^{10}$ research, training, and the European universities. With an ambitious investment program, it is planning to transform the suggested model of economic growth, the financing of the reception and integration of migrants, and the support of those involved in operating the transformation (Bouju et al., 2019: 187).

European Assembly will have the ability to adopt taxes and to enter the very core of the democratic, fiscal, and social compact of member states (Bouju et al., 2019: 188). Granting Assembly the power to enact a common tax on the highest revenues and patrimonies (Hennette et al., 2019: xi) is suggested within the Manifesto in terms of fiscal and social justice and the capacity to invest in the future(Hennette et al., 2019: xi). Within this scope the "exercise of legislative competence" is regulated under Article 10 of T-DEM. Regarding this Article; the Assembly and the Eurogroup, acting in accordance with the ordinary legislative procedure, shall vote on the base and the rate of the common tax on corporate benefits, the progressive tax on high income, the progressive tax on wealth and the tax on carbon emissions which contribute to the democratization budget.

The Budget, if the Assembly so desires, will be financed by four major European taxes(Bouju et al., 2019: 186-187). These are tax on corporate profits, progressive tax on top wealth, progressive tax on high incomes and tax on carbon emissions (Budget, 2018: 3). The aim in the Manifesto is to tax the profits of major firms, "the top incomes, the highest wealth owners, and carbon emissions" (Bouju et al., 2019: 187). Additional to taxes, including existing resources for instance the amount of the cohesion funds currently received by members of the Euro area is also suggested to support the budget (Barack et al. 2018: 50, 51).

\subsection{Tax Competition as a Source of Inequality}

Big multinationals, and the wealthiest taxpayers are benefiting disproportionately from their advantage from the European construction ${ }^{11}$. Fiscal competition between European countries has led to constantly lowering further taxation on the richest and most mobile taxpayers. Taxpayers taking the advantage of mobility, are the large firms, taxpayers with high incomes and assets. This situation has been disturbing the balance to the detriment of the less well-to-do taxpayers, who have witnessed a rise in their deductions. In the form of VAT, other taxes and deductions on salaries (T-DEM, 2018: 7).

Tax policy is one tool available for countries to enhance their competitiveness. On the other hand, tax competition between the countries is leading a rise in social

\footnotetext{
${ }^{10}$ Expenditure power of the European Assembly is assessed under Title 6 of this Article.

${ }^{11}$ https://youtu.be/UyZQnUgWLEA; https://youtu.be/MN3Tdf098sY
} 
inequality indirectly. Tax competition lead the corporate income taxes have fallen dramatically across the world, particularly in EU, as countries have sought to attract business investment. ${ }^{12}$ Several EU countries have introduced tax regimes designed to promote investment. There have important implications in terms of competition. Firstly, competition can produce mismatches between the place where economic activities take place and where the profits resulting from those activities are taxed. Secondly, tax policies in one country can undermine the tax base in another country. ${ }^{13}$ Additionally large scaled multinational companies only take advantage of tax competition among countries while small companies obliged to be subject to higher tax rates. This also constitutes a factor of inequality.

\subsection{Taxation Objectives Followed by the Manifesto}

Public finance theory attributes two main objectives to taxes. One is their fiscal objective, which means that taxes are needed to cover the expenses of the public expenditures (Mutluer vd., 2016: 193-197). In the suggested case of the T-DEM and the Manifesto, fiscal objective is to finance the research, training, the European universities, the reception and integration of migrants (Bouju et al., 2019: 187). All these aims can be reached with the expenditures which is the reflection of fiscal objective.

The objective other than fiscal objective of taxation is its non-fiscal objective, which is to implement fair and balanced income distribution, to provide economic development and to sustain economic stability (Dayanç Kuzeyli, 2019:62). It also aims to find solutions to environmental problems, organize population and health policies etc. (Mutluer vd., 2016:193-197). These are the objectives of the social state. A social state uses taxation not only for its fiscal objectives but also as a tool to ensure social justice and redistribute income and wealth and create incentives for planned development (Öncel vd., 2019:53-54). Taxation according to "ability to pay" is one of the best instruments to redistribute wealth and income equitably (Turhan, 1982: 116-177).

Both in the T-DEM and the Manifesto we witness the social character in the envisaged structure. The most salient features promised through the Manifesto and TDEM are the reduction of "inequalities in incomes" (Budget, 2018:2) and "carbon emissions $\left(\mathrm{CO}^{2}\right)$ " (T-DEM, 2018:3), also enhancing competitiveness "highlighted by globalization and tax competition" (Budget, 2018: 11).

\footnotetext{
12 European Comission (2018). Platform for Tax Good Governance - Competitiveness and Tax Competition, p.2.

${ }^{13}$ European Comission (2018). p.2.
} 


\subsubsection{Reduction of Inequalities in Income}

The solution for the inequalities in incomes is proposed as imposing "a progressive tax on high incomes and high private wealth" (Budget, 2018:11). Most apparent indicators of "ability to pay" are high income and high wealth. Although there are some drawbacks in the press ${ }^{14}$, in the suggested model taxation of both, will eventually contribute to the equality to some extent.

\subsubsection{Income as an indicator of "ability to pay"}

Income taxes have the potential to provide taxation according to "ability to pay" principle; specifically, graduated income (Kendrick, 1939: 93). Income taxes should constitute the highest percentage in the tax system considering their property as direct tax where direct taxes directly consider the ability to pay. However, tax competition threatens to undermine the individual and corporate income taxes, which traditionally have generated the largest share of revenue for modern welfare states (Avi-Yonah, 2000: 1576).

Since the multinational companies and individuals do not have equal tools, taxation of the first rather than the latter is one way of providing progressivity in that sense. Multinational companies have a larger playground; they can use various tax schemes to avoid and evade taxes. As a result of tax competition, foreign tax authorities offer the same service that is in high demand: the possibility of not paying any taxes on dividends, interest, capital gains, wealth, or inheritances (Zucman, 2015: 43). Today, the taxation on top incomes is often even regressive. Taxation of capital is subject to numerous exemptions in the context of this tax competition. It happens that the highest incomes are those which are based in the main on capital yields. This has the effect of reinforcing the concentration of wealth and therefore the inequalities.

Separation principle to provide tax justice is crucial and suggests more taxation on capital than labor. However, tax competition restrains that principle so that inequalities have emerged. From an equity perspective, if capital cannot be effectively taxed, the tax base will generally shift - regressively - toward labor states (Avi-Yonah, 2000: 1578). Thus, tax competition impairs the income tax's ability to redistribute wealth from the rich to the poor.

Progressive taxation is an instrument for redistribution for reducing the inequalities highlighted by globalization and tax competition. Both corporate tax and income tax envisaged in the Manifesto is to rebalance the impaired balance caused by tax competition.

\footnotetext{
${ }^{14}$ https://www.bloombergquint.com/view/piketty-manifesto-won-t-save-europe-from-itself; https://www.theguardian.com/world/2018/dec/09/eu-brexit-piketty-tax-google-facebook-applemanifesto
} 
Regarding the income tax, there are two main features of the income tax proposed by the Manifesto; progressivity is the first feature and narrow scope with only targeting high incomes is the second. The aim is to restore progressive taxation to the upper echelons of incomes by creating additional marginal rates deducted at European level on very high incomes (Budget, 2018: 10). Marginal European additional rates are envisaged as $10 \%$ on annual individual incomes above 100,000 Euros and 20\% on those above 200,000 Euros (Budget, 2018: 10). Considering the higher marginal rate of $40 \%$ applied on average in the EU, the sum of the national and the European rates will be on average $50 \%$ on individual incomes above 100,000 Euros and $60 \%$ on those above 200,000 Euros (Budget, 2018: 10).

Regarding the corporate tax; the Manifesto proposes that the Assembly creates a common European tax at the additional European rate of $15 \%$ of profits (Budget, 2018:8). This European tax will not be exclusive: each Member State will be free to levy a further tax. Additionally, imposition of a minimal rate of taxation equal to $37 \%$ of the profits is also being proposed (Budget, 2018:8). The 37\% includes the 15\% European rate and the national rate. In other words, the minimum rate at the national level is $22 \%$ on the corporate profits.

Differentiation between small and big business could also be voted by the Assembly; a system of additional tax lowered to $10 \%$ for small businesses and raised to 20\% for bigger ones, for equivalent total revenue (Budget, 2018: 8). This proposal suggests progressive corporate income taxation. It is a solution for regressivity which is the consequence of the erosion of the corporate taxes.

\subsubsection{Wealth as an indicator of "ability to pay"}

A wealth tax is a potentially more powerful tool than income, estate, or corporate taxes to address the issue of wealth concentration as it goes after the stock rather than the flow (Saez \& Zucman, 2019: 438). A wealth tax with a high exemption threshold specifically targets the richest and could abate injustice (Saez \& Zucman, 2019: 503) to a certain level.

Direct taxation of personal wealth in the $\mathrm{EU}$ are mainly regressive in the form of taxation of property assets, with no consideration of financial assets (Budget, 2018: 11). Therefore, the setting up of a progressive tax on the most valuable estates as property, financial and professional assets net of debts, are being proposed in the Manifesto (Budget, 2018: 11). According to the Manifesto and T-DEM marginal rate is planned to be $1 \%$ on net individual estates valued at above 1 million Euros and $2 \%$ on those above 5 million Euros. 
Müftüoğlu, Z. \& Dayanç Kuzeyli, N.,N. (2021). "Thoughts on the Manifesto for Democratization of

Europe in the Light of Fiscal Powers", International Journal of Public Finance, 6(2), 211-232.

\subsubsection{Mitigating Environmental Problems}

Mitigating environmental problems and encouraging renewable energy, sustainable development, green mobility can be regarded as non-fiscal objective of taxation which is also followed by the Manifesto. The Manifesto addresses environmental concerns by the means of two main environmental instruments; environmental taxes as carbon tax and environmental tax expenditures aimed at attracting private capital to co-finance new investment projects contributing to a new mode of growth (Budget, 2018: 4).

Within the scope of the Manifesto and T-DEM, as of environmental taxes, establishment of a minimum rate of 30 Euros on each tonne of carbon emitted on European soil is proposed.

For several years now the EU has been in a leading position in the field of reduction of $\mathrm{CO}^{2}$ emissions (Budget, 2018:14). However, the EU does not have the strong mechanism to adopt tax measures. In other words, the European Council, which has representatives from all over the Member States, can only adopt tax measures by unanimous approval (Milne, 2019: 6). Unanimity have been limiting the tax raising power of the EU (Nicodeme, 2006: 5). Additionally, in several European countries, the reduction of emissions is not sufficiently rapid to meet the targets fixed by the Paris Agreement (Budget, 2018: 14).

The European States already subject many sectors of the economy to a tax on carbon emissions (Budget, 2018: 14). This tax can be either explicit or implicit (Budget, 2018: 14). Explicit taxation covers carbon taxes (tax on carbon emissions) and/or Emission Trading System (ETS) (OECD, 2013: 11-23). ETS requires a participation in a market of rights to pollute within which some polluting sectors have to buy quotas of emissions. All the European countries are subject to the ETS (Budget, 2018: 14). In addition to these mechanisms, all the European states also have taxes on energy which act as implicit taxes on carbon (Budget, 2018: 14). Although many sectors in European States subject to tax on carbon emissions; these systems of taxing $\mathrm{CO}^{2}$ are not harmonized between countries and between sectors within countries. Within the same country, the carbon tax can be higher for one sector than for another because of the exemptions or the modulations of the carbon or energy taxation rates (Budget, 2018: 14).

The establishment of a minimum rate of 30 Euros on each tonne of carbon emitted on European soil is relatively low considering international commitments. This is also acknowledged regarding the explanations on the Manifesto (Budget, 2018: 14). However, it is also alleged that the introduction on each tonne of carbon emitted on European soil represents a considerable development (Budget, 2018: 14). Today, despite the high rates in some sectors, others have no carbon tax at all. For instance, effective carbon rates are particularly low in sectors outside road transport, with $70 \%$ of emissions not priced at all and only $4 \%$ of emissions subject to an effective carbon 
rate above EUR $30^{15}$. Although, a minimum rate is proposed within the Manifesto, it is claimed in the explanations on the Manifesto that States will need to adopt higher rates in order to combat with the climate change (Budget, 2018: 15).

The proposal therefore consists in setting up a mechanism establishing a minimum purchase of pollution quotas in the framework of the community system of exchange of emission quotas (Budget, 2018: 14). For the systems outside the ETS the minimum rate amounts to raising the level of the carbon tax if the country has this type of measurement (Budget, 2018: 14). If the rate is lower than the minimum European rate or to introducing an additional tax to ensure that the effective taxation on energy corresponds to a tax at least as high as the minimum rate (Budget,2018:15). The Assembly to vote a calendar providing for a gradual rise in this rate in the years to come, to send a clear signal to those involved in the economy is also proposed within the Manifesto (Budget, 2018: 15).

The overall proposal of carbon tax is overarching but it is not sufficient. Expectations regarding the problems of the ETS weren't addressed with the proposal. The main problem that the EU is struggling today against the ETS is the carbon leakage. Carbon leakage refers to the situation that may occur if, for reasons of costs related to climate policies, businesses were to transfer their production to other countries with laxer emission constraints. This could lead to an increase in their total emissions ${ }^{16}$. However both the Manifesto and T-DEM remained silent on this issue.

\section{Expenditure Power of the European Assembly}

Among the components of the system that the Manifesto establishes, the fourth element can be stated as the expenditure power of the European Assembly. The power to spend is based on the repayment perspective of the T-DEM and in Article 9, it is explained through the foreseeing of the democratisation budget that all or part of the revenues from these own resources will be repaid to the contracting parties.

In the Manifesto, such repayment is directed to the finance of the research, transformation of the economic growth, finance of the immigration process and support of the transformation. In order to meet these targets, the budget is planned to be fixed at 4\% of the European GDP (T-DEM, 2018: 2). In this amount, 0,4\% of GDP will be spent on the European Fund for the transition, 0,4\% of GDP will be spent on financing of the joint management of migration, $0,2 \%$ of GDP will be spent on the agents of the transition, 1\% of GDP will be spent on the financing research and universities to encourage innovation, $2 \%$ of GDP will be spent on the direct transfers to contributing states (T-DEM, 2018: 2, Budget, 2018: 2).

\footnotetext{
${ }^{15}$ https://www.oecd.org/tax/tax-policy/summary-effective-carbon-rates.pdf, (11.02.2021)

${ }^{16}$ https://ec.europa.eu/clima/policies/ets/allowances/leakage_en, (01.11.2020)
} 
In Article 9 of the T-DEM, it is stated that the difference between the revenue paid by each contracting party and the amount of the repayment and expenditure shall not exceed $0,1 \%$ of each State's GDP. With the words of the initiative, "the issue here is not one of creating a 'Transfer payments Europe' which would endeavor to take money from the 'virtuous' countries to give it to those who are less so... The real issue is elsewhere: it is primarily a question of reducing the inequality within the different countries and of investing in the future of all Europeans, beginning of course with the youngest amongst them, with no single country having preference (T-DEM, 2018: 2)." Still, the proportion of the T-DEM is not the argument of which expenditure priorities are best financed at Eurozone level and which of them are at national level (Crowe, 2018: 10).

\section{Conclusion}

The Manifesto is launched to transform the European institutions and policies and concentrated on the solution of specifically addressed problems.

Regarding the brief historical development and evaluations given in the paper, the Manifesto and T-DEM can be shown as a fresh reflection of the same parallel relation between democracy demands and use of fiscal powers. When the suggestions of the Manifesto and T-DEM are considered, the democratization claim lying beneath these papers can easily be found in the formation and the powers of the Assembly. Both in participation mechanism and fiscal powers of the Assembly tend to include new approaches that are different from traditional implementations. The budget proposal suggestion and the rate of compulsory expenditures are other examples of the democracy-oriented characteristic of the Manifesto.

Taxation power constitutes the center of fiscal powers. Four main taxes suggested in the manifesto are in line with the taxation principles specifically with the "ability to pay" principle. The Manifesto also suggests a unique plan on the expenditures which is also directly linked with the fiscal powers. Budget is planned in a way to serve redistribution of wealth and income. As once said in the EUROSAI meeting, it is essential to focus on how to make efficient expenditures, instead of how to collect taxes. The Manifesto seems to achieve that objective with focusing on expenditures. Within this scope both taxation and expenditure are organized in a way to solve the raised problems to some extent. However, there are still some issues that the Manifesto stayed silent like the carbon leakage.

When all these characteristics of the Manifesto are analysed, it is possible to say that fiscal powers are still in the center of the democracy demands and these examined documents are obvious signs of it. Most of the suggestions seem to be addressing the problems and consists concrete solutions. Although there will be upcoming problems with the application of the T-DEM, it is obvious that the existing system is required to change. 


\section{References}

Adalid, S. (2018). "T-Dem Versus Economic Meta-policy: The Means and the Ends", European Papers, 3(1), 19-31.

Adelman, J. \& Delatte, A. N. (2019), 'Europe's constituent moment,' How to democratize Europe, (Eds). Hennette, S. vd., , MA: Harvard University Press, Cambridge, 89-94.

Aidnik, M. (2019). "Europe at the Crossroad: Decline or Reconstruction?", Baltic Journal of European Studies Tallinn University of Technology, 9(4), 29, 237-253.

Aktan, C.C., Dileyici, D., Saraç, Ö. (2002). Vergi, Zulüm ve İsyan, Phoenix Yayınları, Ankara.

Alan, H. (2005). Medieval Law and the Foundations of the State, Oxford University Press, Oxford.

Allemand, F. (2018). "Taking Democracy Seriously in the Euro Area: Reinvigorating the European Parliament's Functions and Responsibilities" European Papers, 3(1), 33-43.

Andrew, B. (2015). Beyond Magna Carta, A Constitution for the United Kingdom, Hart Publishing, Oxford.

Andrew, B., (2016). The Codes of the Constitution, Hart Publishing, North America.

Avi-Yonah, R. S. (2000). "Globalization, Tax Competition, and the Fiscal Crisis of the Welfare State", Harvard Law Review, 113(7), 1573-1676.

Barbou, S. (2018). "Democratising the Eurozone: Some Lessons To Be Drawn from TDem", European Papers, 3(1), 7-17.

Brack, N., Costa, O., Crespy, A. (2018). “The 'T-Dem' for Democratizing the Europe's Economic and Monetary Union - A Critical Appraisal", European Papers, 3(1), 45-57.

Bouju, M.; Chancel, L.; Delatte, A. N.; Hennette, S.; Piketty, T.; Sacriste, G. \& Vauchez, A. (2019), 'Manifesto for the democratization of Europe,' (Eds). Hennette, S. vd., , MA: Harvard University Press, Cambridge, 185-190.

Bulutoğlu, K. (2004). Kamu Bütçesi Kamu Harcamaları Kamu Borçları, Batı Türkeli Yayıncılık, İstanbul.

Cabanes, A. (2019). "The Manifesto For The Democratization of Europe, Democratizing The European Union With A New Treaty: An Audacious Bet", 24 May 19, https://www.transform-network.net/blog/article/democratizing-the-europeanunion-with-a-new-treaty-an-audacious-bet/ 
Crowe, R. (2018). "Is a separate Eurozone budget a good idea?", Ademu Working Paper Series, No: 120, www.ademu-project.eu/publications/working-papers

Crum, B. (2018). "Making Democracy the Priority in EU Economic Governance: Four Theses on the Foundations of the T-Dem Project", European Papers, 3(1), 5965.

Çağan, N. (1985). "Anayasa Çerçevesinde Kamu Maliyesinin Parlamenter Kontrolü", Anayasa Yargısı, (1), 199- 224.

Dayanç Kuzeyli, N.N. (2019). "Taxation as a Preventative Measure for Environmental Protection", Environmental Tax Studies for the Ecological Transition, (Ed.) Ezcurra M. V., Spain, 51-65.

Declaration of Human and Civic Rights, https://www.conseil-constitutionnel.fr/en/ declaration-of-human-and-civic-rights-of-26-august-1789, (17.03.2019).

Edizdoğan, N., Çetinkaya, Ö. (2016). Kamu Bütçesi, Ekin Basın Yayın Dağıtım, 7. Baskı, Bursa.

European Comission (2018). Platform for Tax Good Governance - Competitiveness and Tax Competition, https://ec.europa.eu/taxation_customs/sites/taxation/files/ document_of_com_competitiveness_and_taxation_docx_en.pdf, (25.02.2021)

Fasona, C., (2014). "European Economic Governance and Parliamentary Representation. What Place for the European Parliament?", European Law Journal, 20(2), 164-185.

Feyzioğlu, B. N. (1984). Nazari Tatbiki Mukayeseli Bütçe, Fakülteler Matbaası, Ankara.

Gürsoy, B. (1978). Kamusal Maliye, C. II, Ankara Üniversitesi Siyasal Bilimler Fakültesi Yayınları No. 426, Ankara.

Hennette, S., Piketty, T., Sacriste, G. \& Vauches, A. (2019). How to Democratize Europe, Harvard University Press, USA.

Inter-Parliamentary Union, (2012). Parliaments, Casell and Company Ltd., London.

Kamtsidou, I. (2019), 'In Search of Lost Sovereignty,' How to democratize Europe, (Eds). Hennette , S. vd., , MA: Harvard University Press, Cambridge 131-137.

Kato, J., Tanaka, S. (2019). "Does taxation lose its role in contemporary democratisation? State revenue production revisited in the third wave of democratisation", European Journal of Political Research, 58, 184- 208.

Kendrick, M. S. (1939). "The Ability-to-Pay Theory of Taxation", The American Economic Review, 29(1), 92- 101.

Lupo, N. (2018). “A New Parliamentary Assembly for the Eurozone: A Wrong Answer to a Real Democratic Problem?", European Papers, 3(1), 83-91. 
Maddicott, J., (2015). "Magna Carta and the Origins of Parliament", The Historian, 125, $22-24$.

Maddicott, J. R., (2012). The Origins of the English Parliament 924-1327, Oxford University Press, Oxford.

Manifesto for the Democratization of Europe, (2018). http://tdem.eu/en/manifesto/, (13.02.2020).

Manzella, A. (2018) "Notes on the 'Draft Treaty on the Democratization of the Governance of the Euro Area'", European Papers, 3(1), 93-102.

Milne, J. (2019). "Environmental Taxation", The Oxford Handbook of Comparative Environmental Law. (Ed.) Lees E. \& Viñuales, J. E. 904-925.

Mutluer, K., Öner, E. \& Kesik A. (2016). Teoride ve Uygulamada Kamu Maliyesi, İstanbul Bilgi Üniversitesi Yayınları, İstanbul.

Müftüoğlu, Z. (2019). “Demokrasi ve Mali Yetkiler İlişkisinde Yeni Bir Soluk”, Mali Hukuk Dergisi, 15 (176), 1747-1764.

Nicodème, G. (2006). "Corporate tax competition and coordination in the European Union: What we know? Where do we stand?", European Economy. Economic Papers, No. 250, Brussels, https://ec.europa.eu/economy_finance/ publications/pages/publication718_en.pdf

Öncel, M., Kumrulu, A. \& Çağan, N. (2019). Vergi Hukuku, 28th Edition, Turhan Kitabevi, Ankara.

Passant, J., (2017), "Taxation and the American Revolution", Australasian Accounting, Business and Finance Journal, 11(3), 20-29.

Passant, J., (2016), "Tax and the Forgotten Classes: from the Magna Carta to the English Revolution", Australasian Accounting, Business and Finance Journal, 10(3), 67-88.

Platon, S. (2018), "Democratising the Euro Area Without the European Parliament and Outside of the EU System. A Legal Analysis of the Draft Treaty on the Democratisation of the Governance of the Euro Area ("T-Dem")", European Papers, 3(1), 103-119.

Rozenberg, O. (2018). "The T-Dem as a Realistic Utopia: Why It Fits with What We Know About Parliaments", European Papers, 3(1), 121-125.

Saez, E. \& Zucman, G.(2019). Progressive Wealth Taxation, Brookings Papers on Economic Activity, Brookings Institution Press, 437-533.

Saunders, B. (2019). “No Wall Without Representation: Trump, Taxes and Democratic Inclusion", Think, 18, 35-46.

Sayar, N. (1954). Amme Maliyesi Devlet Bütçe Prensipleri ve Tatbikatı, C. I, Sermet Matbaası, İstanbul. 
Signatories of the Manifesto, (2018). http://tdem.eu/en/signatories/, (13.02.2020).

The Magna Carta (The Great Charter), https://www.constitution.org/eng/ magnacar.pdf, (11.03.2019).

Treaty on the Democratization of the Economic and Social Government of the European Union, (2018). http://tdem.eu/en/treaty/, (13.02.2020).

Zucman, G. (2015). The Hidden Wealth of Nations, The University of Chicago Press, Chicago and London

http://tdem.eu/wp-content/uploads/2018/12/BUDGET_EN.pdf (Budget)

https://youtu.be/UyZQnUgWLEA

https://youtu.be/MN3Tdf098sY 